\title{
Effects of combined extracts of Lepidium meyenii and Allium tuberosum Rottl. on erectile dysfunction
}

\author{
Yi Zhang, Feixian Zhou and Fahuan Ge*
}

\begin{abstract}
Background: Sexual problems are widespread and adversely affect the interpersonal relationships and the quality of life. Currently, synthetic drugs improving sexual function are available, but expenditures for such agents are extremely high. To discover relatively inexpensive, widely available and effective natural drugs, we identified a combined extracts from Lepidium meyenii (maca) root and Allium tuberosum Rottl. (Chinese chive) seed, assessed the effects of this combined extracts on erectile dysfunction, and explored its potential mechanisms.

Methods: The extracts were obtained via supercritical fluid extraction. Male BALB/c mice received doses of extract from single plant or the combined extracts $(200 \mathrm{mg} / \mathrm{kg}$ ) by gastric gavage for $14 \mathrm{~d}$, and Viagra was used as the positive control drug. Sexual behaviour was observed, and concentrations of serum testosterone, nitric oxide (NO), and cyclic guanosine monophosphate (cGMP) in serum as well as in penis were measured. In addition, weights of genital organs were also measured.

Results: The combined extracts of maca root and Chinese chive seed $(1: 1, \mathrm{w} / \mathrm{W})$ had a 45 -fold increase in macamide content compared with maca extract. It also led to significantly higher ejaculation frequency $(P<0.05)$ than single extract from maca root or Chinese chive seed, with no corresponding effect on genital indices. In addition, the NO level in serum $(P<0.01)$ and penis $(P<0.05)$ increased notably, as well as the level of cGMP in penis $(P<0.05)$.

Conclusions: The results indicated that the combined extracts produced better synergistic effects on male sexual function than maca extract or Chinese chive extract alone. These positive effects may involve the upregulation of NO and cGMP concentrations in penis.
\end{abstract}

Keywords: Combined extracts, Maca, Chinese chive seed, Supercritical fluid, Sexual function

\section{Background}

Health concerns related to male sexual function are becoming a global problem due to the great pressure from economic, social relationship and physiological demands. Sexual dysfunction was defined as a heterogeneous group of disorders to respond sexually or to experience sexual pleasure [1]. Sexual dysfunction, especially erectile dysfunction (ED) that is also known as impotence, is a serious public health problem according to NIH report [2]. The increasing number of men seeking treatment for impotence has extended the basic physiological and pharmacological research on sexual performance [3]. Male sexual

\footnotetext{
* Correspondence: gefahuan@mail.sysu.edu.cn

School of Pharmaceutical Sciences, Sun Yat-Sen University, Guangzhou 510006, China
}

excitement is identified by the rise of sexual desire in the brain and the subsequent transmission of relevant signals to the periphery, followed with the penile tumescence necessary for sexual intercourse [4]. Many types of synthetic agents are available for improving sexual function, such as sildenafil, vardenafil, tadalafil, avanafil and udenafil [5-7]. However, long-term use of these drugs can produce negative side effects, such as headache $[5,8]$, muscle pain [8], blurred vision [8], and impairment of renal or hepatic function [9]. Moreover, these agents are expensive. Thus, the exploration of relatively inexpensive, widely available and effective natural drugs from medicinal plants that have been used in alternative therapies is of great significance on global health, particularly for developing countries [10]. 
Lepidium meyenii, which is also known as maca, has been cultivated for thousands of years as a food supplement and a traditional medicine [11]. Several studies have shown that maca possesses many bioactivities, such as enhancing sexual function [12-16], increasing fertility [17] and improving sperm parameters [18-23]. In addition, macamides and macaene are representative marker compounds for quality control of maca $[24,25]$ due to their biologically activities [26]. The seeds of Chinese chive (Allium tuberosum Rottl.) have been used in traditional Chinese medicine for treating impotence and nocturnal emissions [27]. Meanwhile, Chinese chives have been widely cultivated in China and used not only as a foodstuff but also in folkloric medicine. This plant is one of the edible green vegetables consumed daily by Chinese. It has been known that plants which possess the same properties can be combined in order to enhance their biological activities [10, 28, 29]. Several studies have reported that maca extract and the seed of Chinese chive enhanced the sexual function by increasing the number of intromissions [26] or reducing intromission latency [30]. However, there was no experimental investigation performed on the sexual improvement effects of combined extracts from maca and Chinese chive seed.

In the present study, we investigated the effects of single extract from maca root or Chinese chive seed and the combined extracts from these two plants on sexual function in normal male mice, with the objective of finding a relatively inexpensive, widely available and effective aphrodisiac.

\section{Methods}

Plant material

L. meyenii (maca) roots collected from Yunnan, China, were identified by Professor Fa Huan Ge from Sun YatSen University, and its voucher specimen number was No. 201605. A. tuberosum Rottl. (Chinese chive) seeds were purchased from Anguo Qide Chinese Herbal Medicine Sales Co., Ltd. (China), with a voucher specimen (No. 201612). The samples mentioned above were deposited at Nansha Research Institute, Sun Yat-Sen University, Guangzhou, China.

\section{Preparation of extracts}

A customized supercritical fluid extractor (231-50-06) was obtained from Nantong Ruizhi Supercritical Development of Technology Co., Ltd. (China). Before the extract process, the plants were dried under $50^{\circ} \mathrm{C}$ and then pulverized. $300 \mathrm{~g}$ of plant was placed into supercritical fluid extractor. The parameters of the supercritical fluid extraction (SFE) process were set as follows. The pressure and temperature of the extract vessel were set to $35 \mathrm{MPa}$ and $50^{\circ} \mathrm{C}$, respectively, whereas the pressure and temperature of the separator were set to $8 \mathrm{MPa}$ and $55^{\circ} \mathrm{C}$, respectively. $\mathrm{CO}_{2}$ was pumped at a constant flow rate. The extract was collected from the separator after a $1.5 \mathrm{~h}$ extraction. The SFE conditions for maca root extract, Chinese chive extract and the combined extracts were the same, except that extra 95\% ethanol (1:1, $\mathrm{w} / \mathrm{v}$ ) was added as a co-solvent during the extraction for maca root. Besides, $300 \mathrm{~g}$ mixed plants of maca and Chinese chive (1:1, w/w, i.e. $150 \mathrm{~g}$ of each) were used for the extraction of combined extracts. The yield of maca root extract, Chinese chive seed extract and the combined extracts were $1.05,18.0$ and $19.05 \%$, respectively.

\section{Chromatographic analysis of maca root extract, Chinese chive extract and the extract combination}

HPLC analysis of maca root extract, Chinese chive seed extract and the combined extracts were performed using an Ultimate 3000 HPLC system, which consisted of an SR-3000 pump, a DAD-3000 detector and a WPS-3000 autosampler (Thermo Fisher Scientific, China). The experiment was conducted using a Kromasil 100-5C18 column $(250 \times 4.6 \mathrm{~mm}, 5 \mu \mathrm{m})$; the flow rate was set to $1.0 \mathrm{ml} \mathrm{min}^{-1}$ of acetonitrile (solvent $\mathrm{A}$ ) and water ( $0.1 \%$ phosphoric acid) (solvent B) with gradient elution (0-26 min: $85 \%$ A-15\% B; 26-40 min: $85 \%$ A increasing to $95 \%$ A; $40-50 \mathrm{~min}$ : $95 \% \mathrm{~A}-5 \% \mathrm{~B}$ ), and the column temperature set to $40{ }^{\circ} \mathrm{C}$. The detection wavelength was monitored at $210 \mathrm{~nm}[31,32]$.

\section{Animals}

50 male and 100 female BALB/c mice weighing 25-30 g (9-11 weeks of age) were obtained from the laboratory animal centre of Sun Yat-Sen University. Mice were housed in stainless cages $(290 \mathrm{~cm} \times 185 \mathrm{~cm})$ under standard environmental conditions involving a standard diet, water ad libitum, a temperature of $23 \pm 2{ }^{\circ} \mathrm{C}$, a relative humidity of $50-70 \%$, and a day-night cycle with light from 7:00 to 19:00. The study procedures were approved by the Institutional Animal Care and Use Committee (IACUC) of Sun Yat-Sen University (IACUC-DD-17-1009).

\section{Male sexual behaviour}

All female mice were given a subcutaneous injection of $0.02 \mathrm{mg}$ of oestradiol benzoate $48 \mathrm{~h}$ before the start of the experiment [26]. Male mice had experienced sexual behavior training [30]. Sexually experienced male mice were divided into five groups of 10 mice. All animals were treated by oral gavage once daily for 14 consecutive days. Group 1: served as the control and received with 1 $\mathrm{ml}$ of tea oil (camellia); Group 2: treated with $200 \mathrm{mg} / \mathrm{kg}$ (b.w.) of maca extract; Group 3: administrated with $200 \mathrm{mg} / \mathrm{kg}$ (b.w.) of Chinese chive seed extract; Group 4: received with $200 \mathrm{mg} / \mathrm{kg}$ (b.w.) of the combination and Group 5, which served as the positive control group, received $14 \mathrm{mg} / \mathrm{kg}$ of Viagra to enhance sexual behaviour. 
After 5 min for adaptation before the mating experiment, two oestrous female mice were introduced into each male mouse cage [26], and copulation was allowed. Copulatory behaviour was observed for 20 min, and four sexual behaviour parameters were recorded using a camera: mount latency (the time interval from entry into the cage to the mount of any female mouse), mount frequency, ejaculation latency (the time from first intromission to ejaculation) (characterized by longer, deeper pelvic thrusting and slow dismount followed by a period of inactivity) and ejaculation frequency (the number of ejaculations in the given time) [33].

\section{Serum testosterone}

After male mating behaviorial test, $1 \mathrm{ml}$ of blood samples were collected by removing eyeball. Serum was separated by centrifugation at $4000 \mathrm{rpm}$ for $10 \mathrm{~min}$ at room temperature for the measurement of serum testosterone using commercial assay kits purchased from Cusabio Biotech Co., Ltd. (China).

\section{NO and cGMP levels in serum and penis}

Penis tissue were obtained after mice sacrificed. They were sliced into pieces and homogenated. Supernatant was obtained by centrifugation at $5000 \mathrm{~g}$ for $5 \mathrm{~min}$. NO and cGMP levels in supernatant and serum were measured through commercial assay kits purchased from Jiancheng Biological Engineering, Inc. (Nanjing, China) and Meilian Biological Technology (Shanghai, China), respectively.

\section{Sexual organ weight}

The weight of genital organs is another index for sexual function [34]. After 14 days of treatment, the animals were sacrificed by decapitation, and the testis, seminal vesicles, preputial gland and epididymis were carefully removed and weighed. Animals' whole-body weights were also measured.

\section{Statistical analysis}

Statistical analyses were performed using GraphPad Prism 6.0 statistical software. Data were expressed as

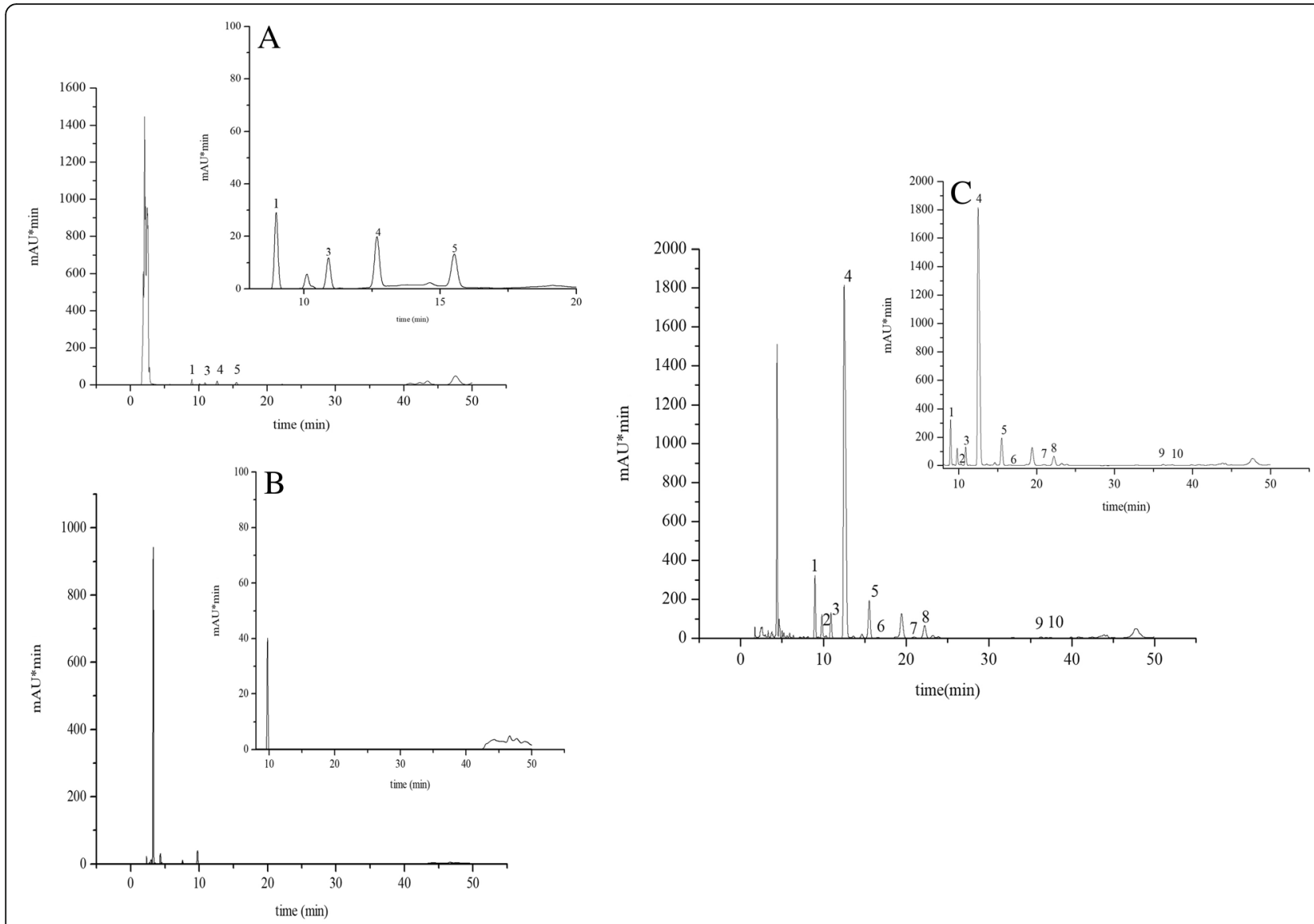

Fig. $1 \mathrm{HPLC}$ chromatographs for macamides and macaene detection of a maca root extract, $\mathbf{b}$ Chinese chive seed extract and $\mathbf{c}$ combined extracts from mixture of maca root and Chinese chive seed (1:1, w/W). The components labelled are: (1) (9Z,12Z,15Z)-octadecatrienoic acid; (2) (9Z,12Z,15Z)-N-(3methoxybenzyl) octadecatrienamide; (3) (9Z,12Z,15Z)-N-benzyloctadecatrienamide; (4) (9Z,12Z)-octadecadienamide; (5) (9Z,12Z)-N-benzyloctadecadienamide; (6) N-benzylpentadecanamide; (7) N-(3-methoxybenzyl) palmitamide; (8) N-benzylpalmitamide; (9) N-(3-methoxylbenzyl) stearamide; (10) N-benzylstearamide) 
Table 1 Effects of maca extract, Chinese chive extract and combined extracts on sexual behaviour in mice (mean \pm SD)

\begin{tabular}{lllll}
\hline Groups & $\begin{array}{l}\text { Mount } \\
\text { latency (s) }\end{array}$ & $\begin{array}{l}\text { Ejaculation } \\
\text { latency (s) }\end{array}$ & $\begin{array}{l}\text { Mount } \\
\text { frequency (s) }\end{array}$ & $\begin{array}{c}\text { Ejaculation } \\
\text { frequency (s) }\end{array}$ \\
\hline Group 1 (control) & $393.90 \pm 116.62$ & $493.00 \pm 92.53$ & $4.70 \pm 1.34$ & $2.20 \pm 1.14$ \\
Group 2 (maca root extract, $200 \mathrm{mg} / \mathrm{kg} / \mathrm{d}$, b.w.) & $311.00 \pm 112.85$ & $509.70 \pm 117.59$ & $6.30 \pm 1.42$ & $2.10 \pm 1.20$ \\
Group 3 (Chinese chive extract, $200 \mathrm{mg} / \mathrm{kg} / \mathrm{d}$, b.w.) & $302.90 \pm 83.08$ & $499.40 \pm 138.98$ & $5.90 \pm 1.20$ & $2.50 \pm 0.71$ \\
Group 4 (combined extracts, 200 mg/kg/d, b.w.) & $282.50 \pm 92.04$ & $459.80 \pm 108.39$ & $6.60 \pm 2.07^{*}$ & $3.50 \pm 0.99^{*}$ \\
Group 5 (Viagra, 14 mg/kg once prior to the & $251.90 \pm 71.90^{*}$ & $381.30 \pm 92.91$ & $7.60 \pm 0.70^{* *}$ & $3.50 \pm 0.97^{*}$ \\
mating experiment) & & & \\
\hline
\end{tabular}

${ }^{*} P<0.05,{ }^{* *} P<0.01$ vs control

mean \pm standard deviation (SD) and significant differences between means were calculated using one-way analysis of variance (ANOVA) followed by Dunnett's test; differences with $P$-values less than 0.05 were regarded as significant.

\section{Results}

Measurement of macamides and macaene in maca root extract and the combined extracts

We screened ten types of macamides and macaene, and their content differences between maca root extract and combined extracts were investigated. The results are shown in Fig. 1. The examined compounds were (9Z,12Z,15Z)-octadecatrienoic acid (1), (9Z,12Z, 15Z)-N-(3-methoxybenzyl)octadecatrienamide (2), (9Z, 12Z,15Z)-N-benzyloctadecatrienamide (3), (9Z,12Z)-octadecadienamide; (4), (9Z,12Z)-N-benzyloctadecadienamide (5), N-benzyl-pentadecanamide (6), N-(3-methoxybenzyl) palmitamide (7), N-benzylpalmitamide (8), N-(3-methoxylbenzyl) stearamide (9) and N-benzylstearamide (10). The macamides were identified via standards that were purchased from Wuhan Huashite Industrial Biotechnology Development Co., Ltd. (China). The content of these compounds in the combined extracts $(202.44 \mathrm{mg} / \mathrm{g})$ was 45 -fold higher than that observed in maca root extract $(4.51 \mathrm{mg} / \mathrm{g}$, and only four of the compounds were detected). Besides, none of the compounds mentioned above were found in Chinese chive seed extract.

\section{Sexual behaviour study}

We investigated the effects of combined extracts from maca root in combination with Chinese chive on sexual function in male mice through the course of 14 days. The results (Table 1) indicated that this combination decreased mount latency and ejaculation latency, and significantly increased ejaculation frequency $(P<0.05)$.

\section{Effects of single extracts and combined extracts on serum} testosterone, NO and cGMP levels in serum and penis

As shown in Table 2, the concentration of NO and cGMP were increased in all experimental groups. The levels of NO were significantly increased in Group $3(98.94 \pm 14.48$, $P<0.05$, in serum) and Group $4(104.69 \pm 8.83, P<0.01$, in serum; $143.18 \pm 0.023, P<0.05$, in penis). Meanwhile, cGMP level in penis was also significantly increased in Group $4(15.01 \pm 1.89, P<0.05)$. However, no significant differences in serum testosterone concentration were observed.

\section{Effects of single extracts and combined extracts on genital indices}

As shown in Table 3, the weights of sexual organs did not significantly change in any group.

\section{Discussion}

Men's sexual function declines over time, and erectile dysfunction (ED) brings negative effects on relationships [35], mood and psychological health [36, 37]. ED is an

Table 2 Effects of maca root extract, Chinese chive extract and combined extracts on testosterone, NO and cGMP levels (mean \pm SD)

\begin{tabular}{|c|c|c|c|c|c|}
\hline \multirow[t]{2}{*}{ Groups } & \multicolumn{3}{|l|}{ Serum } & \multicolumn{2}{|l|}{ Penis } \\
\hline & $\begin{array}{l}\text { Testosterone } \\
\text { (nmol/L) }\end{array}$ & $\mathrm{NO}(\mu \mathrm{mol} / \mathrm{L})$ & $\begin{array}{l}\text { cGMP } \\
(\mu \mathrm{mol} / \mathrm{L})\end{array}$ & $\mathrm{NO}(\mu \mathrm{mol} / \mathrm{L})$ & $\mathrm{cGMP}(\mu \mathrm{mol} / \mathrm{L})$ \\
\hline Group 1 (control) & $15.93 \pm 2.11$ & $82.26 \pm 12.19$ & $6.17 \pm 1.09$ & $116.20 \pm 0.014$ & $12.14 \pm 1.97$ \\
\hline Group 2 (maca root extract, 200 mg/kg/d, b.w) & $15.86 \pm 2.06$ & $94.25 \pm 8.92$ & $6.81 \pm 1.77$ & $118.05 \pm 0.026$ & $12.86 \pm 1.04$ \\
\hline Group 3 (Chinese chive extract, 200 mg/kg/d, b.w) & $15.72 \pm 4.56$ & $98.94 \pm 14.48^{*}$ & $7.03 \pm 1.58$ & $136.90 \pm 1.81$ & $13.21 \pm 1.81$ \\
\hline Group 4 (combined extracts, 200 mg/kg/d, b.w) & $15.83 \pm 2.20$ & $104.69 \pm 8.83^{* *}$ & $7.23 \pm 1.44$ & $143.18 \pm 0.023^{*}$ & $15.01 \pm 1.89^{*}$ \\
\hline Group 5 (Viagra, 14 mg/kg once before mating experiment) & $15.57 \pm 3.30$ & $116.62 \pm 15.19^{*}$ & $8.26 \pm 1.69^{*}$ & $149.73 \pm 0.022^{*}$ & $15.39 \pm 2.19^{*}$ \\
\hline
\end{tabular}

${ }^{*} P<0.05,{ }^{*} P<0.01$ vs control 
Table 3 Effects of maca root extract, Chinese chive extract and combined extracts on genital indexes (mg/10 g) (mean \pm SD)

\begin{tabular}{lllll}
\hline Groups & Testis & Epididymis & Preputial gland & Seminal vesicles \\
\hline Group 1 (control) & $69.49 \pm 7.80$ & $12.59 \pm 1.66$ & $59.72 \pm 18.88$ & $35.65 \pm 5.73$ \\
Group 2 (maca root extract, $200 \mathrm{mg} / \mathrm{kg} / \mathrm{d}$, b.w) & $67.91 \pm 10.10$ & $12.21 \pm 1.96$ & $69.91 \pm 13.49$ & $31.82 \pm 8.34$ \\
Group 3 (Chinese chive extract, $200 \mathrm{mg} / \mathrm{kg} / \mathrm{d}$, b.w) & $68.91 \pm 10.27$ & $13.41 \pm 1.56$ & $66.39 \pm 14.49$ & $30.17 \pm 6.72$ \\
Group 4 (combined extracts, $200 \mathrm{mg} / \mathrm{kg} / \mathrm{d}$, b.w) & $68.85 \pm 11.55$ & $12.60 \pm 1.57$ & $62.40 \pm 14.78$ & $31.78 \pm 6.51$ \\
Group 5 (Viagra, 14 mg/kg once before & $64.62 \pm 9.39$ & $11.78 \pm 1.25$ & $66.32 \pm 13.02$ & $31.34 \pm 6.33$ \\
mating experiment) & & & & \\
\hline
\end{tabular}

inability to achieve or maintain an erection sufficient for satisfactory sexual performance [38]. The maintenance of penile rigidity during erection, intromission, and ejaculation depends on blood supply [39]. Erection occurs after the activation of parasympathetic pathways prompts the release of NO from cavernous nerves and endothelial cells; the ensuing signalling pathways lead to increased cyclic guanosine monophosphate (cGMP) concentrations and decreased intracellular $\mathrm{Ca}^{2+}$ levels, resulting in the relaxation of penile cavernosal smooth muscle, which reduces peripheral arteriolar resistance and permits blood inflow [40, 41]. NO plays an important role in male sexual behaviour $[42,43]$. In present study, we measured concentrations of serum testosterone, NO and cGMP in serum and penis to identify a potential mechanism for sextual behavior improvement of the combined extracts, and genital indices were also assessed. In Group 4, the concentrations of $\mathrm{NO}$ in serum and penis as well as cGMP in penis were significantly increased, which indicated the-improvement in sexual behavior caused by the combined extracts might be regulated by the NO-cGMP pathway. Testosterone, a gonadal hormone, likely enhances male sexual behaviour by increasing NO production $[44,45]$ and stimulating the growth of targeted tissues [46]. Unexpectedly, no significant differences in serum testosterone concentration and genital indices were observed, showing that testosterone did not participate in improving effect of the two plants extract on sexual behavior.

Research has shown that an increase in the ratio of copulating males or changes in parameters of sexual behaviour, such as a reduction in ejaculation latency, indicate improved male sexual performance [47]. The combined extracts decreased mount latency and ejaculation latency and significantly increased ejaculation frequency $(P<0.05)$. The results indicated that the combined extracts had a better efficacy in terms of sexual arousal than both single extracts. Furthermore, the chemical component analysis offered us a comprehensive understanding on active compounds in the combined extracts. The identified number and content of total macamides and macaene obviously increased in the combined extracts, because during the extraction, the extracted Chinese chive oil played a cosolvent role for supercritical $\mathrm{CO}_{2}$. With the help of this intermediate-produced cosolvent, the extraction efficacy was highly elevated, especially for those lipophilic ingredients like (9Z,12Z)-octadecadienamide.

\section{Conclusions}

In summary, a novel combined extracts from maca root and Chinese chive seed produced synergistic effects with respect to improving erectile dysfunction in male mice. The mechanisms for these effects may involve the upregulation of NO and cGMP concentrations in penis.

\section{Abbreviations \\ cGMP: Cyclic guanosine monophosphate; ED: Erectile dysfunction; NO: Nitric oxide}

\section{Authors' contributions}

YZ designed and performed the experiments, analysed the data and wrote the manuscript. FXZ helped design the study and conduct the experiments. FXZ performed extractions, and YZ conducted HPLC analysis. FHG conceived the idea of this study and supervised the research team. All authors read and approved the final version of the manuscript.

\section{Funding}

This work was financially supported by the National Key Research and Development Plan (2017YFC1703102).

\section{Availability of data and materials}

The data analyzed for this study are available from the corresponding author upon reasonable request.

\section{Ethics approval and consent to participate}

The animal experiments were conducted in accordance with the $\mathrm{NIH}$ guide for the care and use of laboratory animals (NIH Publication No. 80-23; revised 1978). The study was approved by the Institutional Animal Care and Use Committee (IACUC) of Sun Yat-sen University (IACUC-DD-17-1009).

Consent for publication

Not applicable.

\section{Competing interests}

The authors declare that they have no competing interests.

Received: 24 January 2018 Accepted: 3 June 2019

Published online: 18 June 2019

\section{References}

1. American Psychiatric Association, editor. Diagnostic and statistical manual of mental disorders: DSM-5. 5th ed. Washington, D.C.: American Psychiatric Association; 2013. American Psychiatric Association. DSM-5 Task Force

2. Singh R, Ali A, Jeyabalan G, Semwal A, Jaikishan. An overview of the current methodologies used for evaluation of aphrodisiac agents. J Acute Dis. 2013;2(2):85-91. 
3. Cicero AG, Bandieri E, Arletti R. Lepidium meyenii Walp. improves sexual behaviour in male rats independently from its action on spontaneous locomotor activity. J Ethnopharmacol. 2001;75:225-9.

4. Ayman AS, Islam MS, Hany AZ, Sawsan AMA, Abdullah NA. Effect of sexual excitation on testosterone and nitric oxide levels of water buffalo bulls (Bubalus bubalis) with different categories of sexual behavior and their correlation with each other. Anim Reprod Sci. 2017;181:151-8.

5. Steve KW, Arnold M. Novel therapeutic targets for erectile dysfunction. Maturitas. 2012;71:20-7.

6. Gur S, Sikka SC, Hellstrom WJ. Novel phosphodiesterase-5 (PDE5) inhibitors in the alleviation of erectile dysfunction due to diabetes and ageinginduced oxidative stress. Expert Opin Investig Drugs. 2008;17:855-64.

7. John PM, Massimo FM. Aphrodisiacs from plant and animal sources-a review of current scientific literature. Food Res Int. 2011;44:840-50.

8. Sandroni P. Aphrodisiacs past and present: a historical review. Clin Auton Res. 2001;11(5):303-7.

9. Giuliano F, Jackson G, Montorsi F, Martin-Morales A, Raillard P. Safety of Viagra citrate: review of 67 double-blind placebo-controlled trials and the postmarketing safety database. Int J Clin Pract. 2010;64(2):240-55.

10. Massoma Lembè D, Gasco M, Gonzales GF. Fertility and estrogenic activity of Turraeanthus africanus in combination with Lepidium meyenii (Black maca) in female mice. Eur J Integr Med. 2012;4:e345-51.

11. Wang $Y$, Wang $Y$, McNeil B, Harvey LM. Maca: an Andean crop with multipharmacological functions. Food Res Int. 2007;40:783-92.

12. Lentz A, Gravitt K, Carson CC, Marson L. Acute and chronic dosing of Lepidium meyenii (Maca) on male rat sexual behavior. J Sex Med. 2007;4:332-9.

13. Lentz AC, Carson CC III, Marson L. Does the new herbal supplement "Maca" enhance erectile function or female sexual function? Semin Prev Alt Med. 2006;:85-90.

14. Gonzales GF, Cordova A, Vega K, Chung A, Villena A, Gonez C, Castillo S. Effect of Lepidium meyenii (maca) on sexual desire and its absent relationship with serum testosterone levels in adult healthy men. Andrologia. 2002;34:367-72.

15. Shin BC, Lee MS, Yang EJ, Lim HS, Ernst E. Maca (L. meyenii) for improving sexual function: a systematic review. BMC Complement Altern Med. 2010;10:44.

16. Chung F, Rubio J, Gonzales C, Gasco M, Gonzales GF. Dose-response effects of Lepidium meyenii (Maca) aqueous extract on testicular function and weight of different organs in adult rats. J Ethnopharmacol. 2005;98:143-7.

17. Uchiyama F, Jikyo T, Takeda R, Ogata M. Lepidium meyenii (Maca) enhances the serum levels of luteinising hormone in female rats. J Ethnopharmacol. 2014;151:897-02.

18. Clement C, Kneubuhler J, Urwyler A, Witschi U, Kreuzer M. Effect of maca supplementation on bovine sperm quantity and quality followed over two spermatogenic cycles. Theriogenology. 2010;74:173-83.

19. Gonzales GF, Gasco M, Cordova A, Chung A, Rubio J, Villegas L. Effect of Lepidium meyenii (Maca) on spermatogenesis in male rats acutely exposed to high altitude (4340 m). J Endocrinol. 2004;180:87-95.

20. Gonzales GF, Ruiz A, Gonzales C, Villegas L, Cordova A. Effect of Lepidium meyenii (maca) roots on spermatogenesis of male rats. Asian J Androl. 2001;3(3):231-3.

21. Rubio J, Riqueros MI, Gasco M, Yucra S, Miranda S, Gonzales GF. Lepidium meyenii (maca) reversed the lead acetate induced-damage on reproductive function in male rats. Food Chem Toxicol. 2006:44:1114-22.

22. Gonzales GF, Gonzales-Castaneda C, Gasco M. A mixture of extracts from Peruvian plants (black maca and yacon) improves sperm count and reduced glycemia in mice with streptozotocin-induced diabetes. Toxicol Mech Methods. 2013:23:509-18.

23. Melnikovova I, Tomas F, Huml L, Kolarova M, Lapcik O, Cusimamani E. Effect of Lepidium meyenii on semen quality and reproductive hormones level in healthy adult men. Climacteric. 2014;17:87.

24. Ganzera M, Zhao J, Muhammad I, Khan IA. Chemical profiling and standardization of Lepidium meyenii (maca) by reversed phase high performance liquid chromatography. Chem Pharm Bull. 2002;50:988-91.

25. McCollom MM, Villinski JR, MCPhail KL, Craker LE, Gafner S. Analysis of macamides in samples of maca (Lepidium meyenii) by HPLC-UV-MS/MS. Phytochem Anal. 2005;16:463-9.

26. Zheng BL, He K, Kim C, Rogers LL, Shao Y, Huang ZY, Lu Y, Yan SJ, Qien LC, Zheng QY. Effect of a lipidic extract from Lepidium meyenii on sexual behavior in mice and rats. Urology. 2000;55(4):598-02.

27. Jiangsu New Medicinal College. The dictionary of Chinese herbal medicines, vol. 2. Shanghai: Shanghai People's Publishing Press; 1979. p. 278.

28. Moundipa PF, Ngouela S, Kamtchouing P, Tsamo E, Tchouanquep FM, Carreau S. Effects of extracts from Hibiscus macranthus and Basella alba mixture on testosterone production in vitro in adult rat testes slices. Asian J Androl. 2006;8(1):111-4.

29. Telefo PB, Moundipa PF, Tchana AN, Tchouanguep DC, Mbiapo FT. Effects of an aqueous extract of Aloe buettneri, Justicia insularis, Hibiscus macranthus, Dicliptera verticillata on some physiological and biochemical parameters of reproduction in immature female rats. J Ethnopharmacol. 1998;63(3):193-200.

30. Hu GH, Lu YH, Mao RG, Wei DZ, Ma ZZ, Zhang H. Aphrodisiac properties of Allium tuberosum seeds extract. J Ethnopharmacol. 2009;122:579-82.

31. Shao JL, Fan JL, Yang DS, Liu XY, Du L, Wang L, Liu HC. Simultaneous determination of eight macamides in Lepidium meyenii Walp. by HPLCPAD. Jiangsu J Agr Sci. 2016;32(1):229-33.

32. Xia C, Deng JL, Zhang YJ, Chen J. Determination of contents of N-Benzylhexadecanamide in Sichuan Maca by HPLC. Chem Bioeng. 2017;34(2):68-70.

33. Tang XL, Olatunji OJ, Zhou YF, Hou XL. In vitro and in vivo aphrodisiac properties of the seed extract from Allium tuberosum on corpus cavernosum smooth muscle relaxation and sexual behavior parameters in male Wistar rats. BMC Complement Altern Med. 2017;17:510-9.

34. Ponmanickam P, Palanivelu K, Govindaraj S, Baburajendran R, Habara Y, Archunan G. Identification of testosterone-dependent volatile compounds and proteins in the preputial gland of rat Rattus norvegicus. Gen Comp Endocrinol. 2010;167(1):35-43.

35. Muller MJ, Ruof J, Graf-Morgenstern M, Porst H, Benkert O. Quality of partnership in patients with erectile dysfunction after Viagra treatment. Pharmacopsychiatry. 2001;34(3):91-5.

36. Litwin MS, Nied RJ, Dhanani N. Health-related quality of life in men with erectile dysfunction. J Gen Intern Med. 1998:13(3):159-66.

37. Shabsigh R, Klein LT, Seidman S, Kaplan SA, Lehrhoff BJ, Ritter JS. Increased incidence of depressive symptoms in men with erectile dysfunction. Urology. 1998;52(5):848-52.

38. Yafi FA, Jenkins L, Albersen M, Corona G, Isidori AM, Goldfarb S, Maggi M, Nelson CJ, Parish S, Salonia A, Tan R, Mulhall JP, Hellstrom W. Erectile dysfunction. Nat Rev Dis Primers. 2016. https://doi.org/10.1038/nrdp.

39. Lue TF. Erectile dysfunction. N Engl J Med. 2000;342:1802-13.

40. Senger PL. Reproductive behavior. In: Senger PL, editor. Pathways to pregnancy and parturition. Second edition. Current conceptions. Pullman: Washington State University, Research and Technology Park; 2003. p. 250-3.

41. Lue TF, Tanagho EA. Physiology of erection and pharmacological management of impotence. J Urol. 1987;137:829-36.

42. Estrada-Reyes R, Carro-Juarez M, Martınez-Mota L. Pro-sexual effects of Turnera diffusa wild (Turneraceae) in male rats involves the nitric oxide pathway. J Ethnopharmacol. 2013;146:164-72.

43. Burnett AL. Nitric oxide in the penis-science and therapeutic implications from erectile dysfunction to priapism. J Sex Med. 2006;3:578-82.

44. Vignozzi L, Corona G, Petrone L, Filippi S, Morelli AM, Forti G, Maggi M. Testosterone and sexual activity. J Endocrinol Investig. 2005;28:39-44.

45. Zvara P, Sioufi R, Schipper HM, Begin LR, Brock GB. Nitric oxide mediated erectile activity is a testosterone dependent event: a rat erection model. Int I Impot Res. 1995;7:209-19.

46. Chauhan NS, Rao CV, Dixit VK. Effect of Curculigo orchioides rhizomes on sexual behaviour of male rats. Fitoterapia. 2007;78:530-4.

47. Fernandez-Guasti A, Rodriguez-Manzo G. Pharmacological and physiological aspects of sexual exhaustion in male rats. Scand J Psychol. 2003:44:257-63.

\section{Publisher's Note}

Springer Nature remains neutral with regard to jurisdictional claims in published maps and institutional affiliations.

Ready to submit your research? Choose BMC and benefit from:

- fast, convenient online submission

- thorough peer review by experienced researchers in your field

- rapid publication on acceptance

- support for research data, including large and complex data types

- gold Open Access which fosters wider collaboration and increased citations

- maximum visibility for your research: over $100 \mathrm{M}$ website views per year

At $\mathrm{BMC}$, research is always in progress.

Learn more biomedcentral.com/submissions 